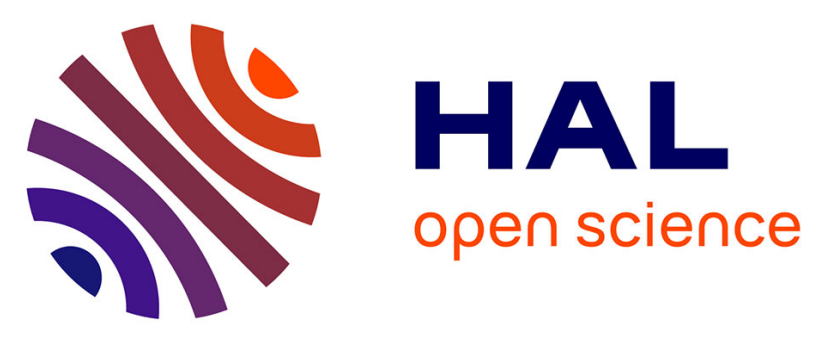

\title{
The tropical brown alga Lobophora variegata as a bioindicator of mining contamination in the New Caledonia lagoon: a field transplantation study
} Laetitia Hédouin, Paco Bustamante, Renaud Fichez, Michel Warnau

\section{- To cite this version:}

Laetitia Hédouin, Paco Bustamante, Renaud Fichez, Michel Warnau. The tropical brown alga Lobophora variegata as a bioindicator of mining contamination in the New Caledonia lagoon: a field transplantation study. Marine Environmental Research, 2008, 66 (4), pp.438-444. 10.1016/j.marenvres.2008.07.005 . hal-00326628

\section{HAL Id: hal-00326628 \\ https://hal.science/hal-00326628}

Submitted on 3 Oct 2008

HAL is a multi-disciplinary open access archive for the deposit and dissemination of scientific research documents, whether they are published or not. The documents may come from teaching and research institutions in France or abroad, or from public or private research centers.
L'archive ouverte pluridisciplinaire HAL, est destinée au dépôt et à la diffusion de documents scientifiques de niveau recherche, publiés ou non, émanant des établissements d'enseignement et de recherche français ou étrangers, des laboratoires publics ou privés. 
1 The tropical brown alga Lobophora variegata as a bioindicator of mining

2 contamination in the New Caledonia lagoon: a field transplantation study 3

4 Laetitia Hédouin $^{1-3}$, Paco Bustamante ${ }^{2}$, Renaud Fichez ${ }^{3}$ and Michel Warnau ${ }^{1 *}$

5

$6 \quad{ }^{1}$ International Atomic Energy Agency - Marine Environment Laboratories (IAEA-MEL), 4

7 Quai Antoine 1er, MC-98000 Principality of Monaco

$8 \quad{ }^{2}$ Littoral, Environnements et Sociétés (LIENSs), UMR 6250 CNRS-Université de La

9 Rochelle, 2 rue Olympe de Gouges, F-17042 La Rochelle cedex 01

$10{ }^{3}$ Institut de Recherche pour le Développement (IRD-Nouméa Center), BP A5, 9884 Nouméa

11 cedex, New-Caledonia

12

$13 *$ Corresponding Author: Michel Warnau 
ABSTRACT.

Previous field and laboratory studies have identified the alga Lobophora variegata as a good candidate for biomonitoring metal contamination in the New Caledonia lagoon which is subjected to intensive and extensive metal inputs from land-based mining activities. The aim of this work was to further assess the bioindicative potential of this species by investigating, in the field, its bioaccumulation capacity for local key contaminants, i.e. $\mathrm{Ag}, \mathrm{As}, \mathrm{Cd}, \mathrm{Co}, \mathrm{Cr}$, $\mathrm{Cu}, \mathrm{Mn}, \mathrm{Ni}$ and $\mathrm{Zn}$. Algae from clean and contaminated sites were cross-transplanted for a period of three months in order to determine the in situ uptake and depuration kinetics of the nine elements. Results indicate that algae transplanted to the contaminated site displayed a significant linear increase in concentration with time for $\mathrm{Ag}, \mathrm{As}, \mathrm{Cd}, \mathrm{Co}, \mathrm{Cr}, \mathrm{Cu}, \mathrm{Mn}$ and $\mathrm{Ni}$. In contrast, algae transplanted to the clean site did not show major depuration of these elements, except for Co. Overall, L. variegata showed a rapid temporal response in metal uptake, especially for the elements intensively released into the coastal environment of New Caledonia (viz., $\mathrm{Co}, \mathrm{Cr}, \mathrm{Mn}$ and Ni). This species appears therefore as an excellent bioindicator species of metal contamination in this area. Our results also provide background information necessary for using L. variegata under in situ experimental conditions so as to provide better quantitative information on ambient metal contamination levels. The wide distribution of L. variegata in tropical areas further enhances its potential as a bioindicator species of metal contamination in other tropical coastal environments.

41 Keywords: Metals; Bioaccumulation; Depuration; Biomonitoring; Sentinel organism;

Tropical environment 


\section{Introduction}

Most studies dealing with bioindicators in aquatic systems focus on contaminant concentrations in various species, whereas very few have been conducted to actually test the validity of the alleged bioindicator species (see e.g., Warnau et al., 1996; Rainbow, 2002; Coteur et al., 2003). The lack of background scientific information necessary to derive proper biological tools to be used in environmental monitoring programmes is even more pronounced in coral reef ecosystems, despite their increasingly acknowledged sensitivity to environmental stresses (e.g., Hoegh-Guldberg, 1999). In this respect, New Caledonia is a very good example. This small SE Pacific tropical Island contains one of the major Ni ore deposits worldwide and, for about a century, its economic development has been essentially based on Ni mining activities. Its huge coral reef lagoon is naturally influenced by natural erosion of the metal-rich soils and associated metal inputs (Labrosse et al., 2000). In addition, intense local mining activities result in substantial anthropogenic inputs of metals into the lagoon and thereby constitute a threat to the local coastal ecosystems (e.g., Bird et al., 1984; Laganier, 1991; Ambatsian et al., 1997). Despite these important metal contamination sources, ecotoxicological information regarding the lagoon is very scarce (Labrosse et al., 2000; Metian et al., 2005, 2008a,b; Fichez et al., 2005; Hédouin et al., 2006, 2007, 2008).

The usefulness of bioindicator species to monitor the extent of the contamination in the marine environment is now well established (e.g., O'Connor, 1998; Warnau and Bustamante, 2007). Among marine organisms, brown macroalgae are known to efficiently accumulate metals from their environment (e.g. Försberg et al., 1988; Phillips, 1990). Therefore, the Phaeophyceae family has been used as indicators of metal contamination since the early seventies (Burrows, 1971; Bryan, 1983; Söderlund et al., 1988). However, as the general rule mentioned earlier, these studies were mainly conducted in temperate zones and far less 
attention has been paid to the tropical and sub-tropical areas (e.g., Karez et al., 1994; Amado Filho et al., 1999).

In New Caledonia, the brown alga Lobophora variegata has recently been suggested as a possible bioindicator organism. Indeed, this species is of reasonable size, sessile, easily collectable and displays high metal bioaccumulation capacity (Metian et al., 2006, 2008b). In particular, Metian et al. (2006, 2008b) demonstrated that the alga concentrates $\mathrm{Cd}, \mathrm{Co}, \mathrm{Cr}$, $\mathrm{Mn}, \mathrm{Ni}$ and $\mathrm{Zn}$ in direct proportion to the dissolved element concentrations in ambient seawater, which is one of the most important pre-requisites for selecting a bioindicator species (Phillips, 1990; Warnau et al., 1997). In this respect, L. variegata tissue concentrations were thousands of times higher relative to those in seawater and metal retention efficiency was shown to be independent of the exposure concentration (Metian et al., 2006, 2008b). The latter laboratory study provided essential information regarding the excellent bioindicative potential of L. variegata; however, information on the metal bioaccumulation behaviour of the alga is still needed in the field.

The aim of the present work was therefore to determine the bioconcentration and retention capacities of L. variegata for nine selected elements (Ag, $\mathrm{As}, \mathrm{Cd}, \mathrm{Co}, \mathrm{Cr} \mathrm{Cu}, \mathrm{Mn}, \mathrm{Ni}$ and $\mathrm{Zn}$ ) under field conditions, using cross-transplantation experiments in the New Caledonia lagoon. These experiments were carried out in order to determine whether transplanted algae could concentrate and eliminate the selected elements up to similar levels and at similar rates as resident populations, as well as to assess the period of time necessary for them to reach concentrations representative of the resident populations. 
2. Materials and methods

91

2.1. Selection of the transplantation locations

93

Recent studies have provided data on element concentrations in different areas of the lagoon of New Caledonia (Hédouin 2006; Hédouin et al. 2008; Metian et al. 2008a) and allowed the selection of a "reference" site and a "contaminated" site where the crosstransplantation experiments were carried out. Maa Bay was identified as a suitable "reference" site because of the low element concentrations measured in algae as well as in sediments, and Boulari Bay was identified as the "contaminated" site as it displays very high concentrations in both the resident algae and sediments, due to terrigenous inputs from both natural and mining-induced soil erosion (Fig. 1).

102

103

2.2. Experimental design

104

Fifty specimens of L. variegata were collected in February 2005 in Maa Bay. Ten individuals were analysed for their content of $\mathrm{Ag}, \mathrm{As}, \mathrm{Cd}, \mathrm{Co}, \mathrm{Cr} \mathrm{Cu}, \mathrm{Mn}, \mathrm{Ni}$ and $\mathrm{Zn}$ (see below) in order to establish baseline concentrations at the beginning of the experiment $\left(\mathrm{t}_{0}\right)$. The 40 remaining algae were transplanted for $103 \mathrm{~d}$ in Boulari Bay (contaminated site). The same number of algae from Boulari Bay was transferred to Maa Bay at the same time in order

110 to follow the depuration of the contaminants from these algae.

111 From this time onwards, 5 individuals of the resident population and 5 transplanted organisms (in both reference and contaminated sites) were collected at different time intervals 
over a 103-d period in order to compare the change and variability of element concentrations

114 in transplanted and resident algae.

At $\mathrm{t}_{0}$, all organisms, including control resident specimens, were placed in plastic cages $(100 \times 100 \times 50 \mathrm{~cm})$ anchored between 4 and $5 \mathrm{~m}$ depth. Cages were made of $1-\mathrm{cm}$ mesh plastic net to ensure free seawater circulation within the cage. Transplanted and control algae were collected by SCUBA diving, transported to the laboratory in clean, acid-washed PET bags, and processed for element analyses the same day (typically within 4 to $5 \mathrm{hrs}$ ).

\subsection{Sample preparation and analyses}

In the laboratory, the algae were cleansed of their epiphytes and any attached sediment grains by gentle scrubbing and rinsing several times in seawater from their respective sampling sites. The algae were then weighed (wet wt), dried at $60^{\circ} \mathrm{C}$ until constant weight, and weighed again (dry wt) before being stored in acid-washed, hermetically sealed PET containers until further analysis.

Algal samples (200-300 mg dry wt) were digested using $6 \mathrm{ml}$ of $65 \% \mathrm{HNO}_{3}, 2 \mathrm{ml}$ of 30 $\% \mathrm{HCl}$ and $0.5 \mathrm{ml}$ of $40 \% \mathrm{HF}$ (Merck, suprapur quality). Acidic digestions were first carried out overnight at room temperature, then using a MARS V microwave (30-min long linear increase up to $115^{\circ} \mathrm{C}$ followed by $15 \mathrm{~min}$ at $115^{\circ} \mathrm{C}$ ) to complete the mineralization. Each sample volume was then adjusted to $50 \mathrm{ml}$ with milli-Q quality water.

Elements were analysed using a Varian Vista-Pro ICP-OES (As, $\mathrm{Cr}, \mathrm{Cu}, \mathrm{Mn}, \mathrm{Ni}$, and $\mathrm{Zn}$ ) or a Varian ICP-MS Ultra Mass 700 (Ag, Cd and Co). Three control samples (two certified reference materials -CRM- and one blank), treated and analysed in the same way as the samples, were included in each analytical batch. The CRM were dogfish liver DOLT-3 (NRCC) and lobster hepatopancreas TORT-2 (NRCC). The results from CRM analysis 
138 indicated a recovery ranging from $81 \%(\mathrm{Ni})$ to $113 \%(\mathrm{Zn})$ (Table 1). The detection limits

139 were $31(\mathrm{As}), 1.3(\mathrm{Cr}), 3.8(\mathrm{Cu}), 0.15(\mathrm{Mn}), 1.1(\mathrm{Ni})$ and $2.4(\mathrm{Zn}) \mu \mathrm{g} \mathrm{g}^{-1}$ dry wt for ICP-OES 140 and $0.1(\mathrm{Ag}), 0.15(\mathrm{Cd})$ and $0.1(\mathrm{Co}) \mu \mathrm{g} \mathrm{g} \mathrm{g}^{-1}$ dry wt for ICP-MS.

\subsection{Statistical analyses}

Uptake (eq. 1) and depuration (eq. 2) kinetics of the elements were determined using simple linear regression equations:

where $C_{t}$ and $C_{0}$ are the element concentration $\left(\mu \mathrm{g} \mathrm{g}^{-1}\right.$ dry wt) in algae at time $t(d)$ and 0 , (Temara et al. 1998). Constants of the equation and their statistics were estimated by iterative adjustment of the model and Hessian matrix computation using the nonlinear curve-fitting routines in the Statistica ${ }^{\circledR}$ 5.2.1 software.

On the first day $\left(\mathrm{t}_{0}\right)$ of the transplantations, element concentrations in algae from the reference site were compared to those from contaminated stations using one-way analysis of variance (ANOVA) followed by the multiple comparison test of Tukey (Zar 1996). Element

159 concentrations at the end of transplantation period were also compared to those of resident

160 algae from the transplanted stations (1-way ANOVA). In addition, when element concentrations in resident algae showed a significant increase/decrease with time, the slope of 
162 the regression $\left(\mathrm{k}_{\mathrm{u}}\right.$ or $\left.\mathrm{k}_{\mathrm{e}}\right)$ was compared with the slope of the regression for transplanted algae

163 (Zar 1996). The level of significance for statistical analyses was always set at $\alpha=0.05$.

\section{Results}

3.1. Starting day of transplantation

At $\mathrm{t}_{0}$, the concentrations of $\mathrm{Ag}, \mathrm{As}, \mathrm{Co}, \mathrm{Cr}, \mathrm{Mn}$ and $\mathrm{Ni}$ were significantly higher in algae $\mathrm{Mn}$ and $\mathrm{Ni},<0.02$ for $\mathrm{Cr}$ ), whereas no significant difference was found for $\mathrm{Cd}, \mathrm{Cu}$ and $\mathrm{Zn}$ concentrations between the two sites (see Figs 2 and 3).

173

3.2. Transplantation from Maa Bay (reference) to Boulari Bay (contaminated site) (Fig. 2)

175

Element concentrations in the resident L. variegata population from Maa Bay did not vary significantly during the experiment for all elements, indicating that any variation in

178 concentrations in algae transplanted to Boulari Bay were actually related to changes in environmental conditions. Since the cages in Boulari Bay were damaged after 71d, the transplantation experiment had to stop at that time and could not last for the expected 103-d period.

In algae transplanted to Boulari Bay, $\mathrm{Zn}$ was the only element which did not show a statistically significant increase in concentrations during the transplantation period $\left(\mathrm{p}_{\text {regression }}\right.$ slope $=0.5)($ Fig. 2). In contrast, $\mathrm{Ag}, \mathrm{As}, \mathrm{Cd}, \mathrm{Co}, \mathrm{Cr}, \mathrm{Cu}, \mathrm{Mn}$ and $\mathrm{Ni}$ increased linearly over the observation period of $71 \mathrm{~d}\left(\mathrm{R}^{2}=0.71-0.90\right.$ for $\mathrm{Ag}, \mathrm{Co}, \mathrm{Cr}, \mathrm{Mn}$ and $\mathrm{Ni}$, and $\mathrm{R}^{2}=0.22-0.41$ 
magnitude than that for the other elements. The concentrations of $\mathrm{Cr}, \mathrm{Mn}$ and $\mathrm{Ni}$ increased respectively from $6.5,63$ and $9.0 \mu \mathrm{g} \mathrm{g}^{-1}$ dry wt at the beginning of the experiment up to 192 , 516 and $280 \mu \mathrm{g} \mathrm{g}^{-1}$ dry wt after $71 \mathrm{~d}$ of transplantation.

At the end of the transplantation period, the concentrations of $\mathrm{Ag}, \mathrm{Cd}, \mathrm{Co}, \mathrm{Cr}, \mathrm{Cu}, \mathrm{Mn}$ and $\mathrm{Ni}$ in algae in Boulari Bay were significantly higher in transplanted algae than in the resident population (from 1.6 to 2.9 fold; $\mathrm{p}_{\text {Tukey }}$ always $<0.003$ ). No significant difference was observed for As.

\subsection{Transplantation from Boulari Bay (contaminated) to Maa Bay (reference site) (Fig. 3)}

$$
\text { In the course of the transplantation from the contaminated site to the reference site, Co }
$$
concentrations decreased linearly $\left(\mathrm{k}_{\mathrm{e}}: 0.036 \mu \mathrm{g} \mathrm{g}^{-1}\right.$ dry wt $\left.\mathrm{d}^{-1} ; \mathrm{R}^{2}=0.1\right)$ whereas $\mathrm{Mn}$ and $\mathrm{Zn}$ concentrations increased linearly $\left(k_{\mathrm{u}}=1.87\right.$ and $0.30 \mu \mathrm{g} \mathrm{g}^{-1}$ dry wt $\mathrm{d}^{-1}, \mathrm{R}^{2}=0.53$ and 0.15 , respectively) (Fig. 3). With the exception of the measurements done at day 16, Ag concentrations in algae were below the detection limit $\left(<0.1 \mu \mathrm{g} \mathrm{g}^{-1}\right.$ dry wt $)$, precluding any regression fit calculation. No significant linear regression could be calculated for all the other elements.

No significant variation in element concentrations was found in the L. variegata resident population in Boulari Bay during the observation period, except for $\mathrm{Mn}$ and $\mathrm{Zn}$. For these two latter metals, a significant increase in concentration was observed. The corresponding estimated uptake rate constants $\left(\mathrm{k}_{\mathrm{u}}=3.18\right.$ and $0.39 \mu \mathrm{g} \mathrm{g} \mathrm{g}^{-1}$ dry wt $\mathrm{d}^{-1}$ for $\mathrm{Mn}$ and $\mathrm{Zn}$ respectively, $\mathrm{p}<0.04)$ were not significantly different from those calculated for the Boulari Bay algae that were transplanted in Maa Bay. 
At the end of the experiment, Co and Mn concentrations were significantly higher ( $\mathrm{p}_{\text {Tukey }}$

$211=0.03$ and 0.0002 , respectively) in transplanted algae than in the resident population (1.9 fold

212 higher for Co and 5.2 for $\mathrm{Mn}$ ), whereas no significant difference was found for $\mathrm{Zn}$.

\section{Discussion}

When transplanted from the reference (Maa Bay) to the contaminated site (Boulari Bay), the tropical brown alga $L$. variegata readily took up $\mathrm{Ag}, \mathrm{As}, \mathrm{Cd}, \mathrm{Co}, \mathrm{Cr}, \mathrm{Cu}, \mathrm{Mn}$ and $\mathrm{Ni}$, which demonstrated that a significant proportion of the ambient trace metal contamination was occurring in bioavailable chemical forms and confirmed that the target algal species has a strong potential to accumulate these contaminants.

In a comparable one-month duration transplantation experiment in Sepatiba Bay, Brazil, Amado Filho et al. (1999) observed that the brown alga Padina gymnospora was able to rapidly accumulate $\mathrm{Cd}$ and $\mathrm{Zn}$, which suggests that a strong bioaccumulation capacity is a general feature among brown algae. This further supports the suggestion to consider this taxonomic group as metal bioindicators in tropical areas.

After approximately one month $L$. variegata individuals transplanted to the contaminated site reached $\mathrm{Ag}, \mathrm{As}, \mathrm{Cd}, \mathrm{Co}, \mathrm{Cr}, \mathrm{Cu}, \mathrm{Mn}$ and $\mathrm{Ni}$ concentrations similar to those measured in resident algae from Boulari Bay (see Fig. 2). Surprisingly, beyond that period, concentrations of $\mathrm{Ag}, \mathrm{Cd}, \mathrm{Co}, \mathrm{Cr}, \mathrm{Cu}, \mathrm{Mn}$ and $\mathrm{Ni}$ continued to increase, reaching values significantly higher than those measured in the resident population. These observations suggest that the resident 231 algae, subjected to chronic elevated metal exposure, could have developed adaptive response(s) to handle high levels of contamination by, e.g., regulating the intake and/or depuration rate of the contaminants, through either physiological or genetic adaptation

234 (Klerks and Weis 1987; Warnau et al. 1995; Ma et al. 2000). This is further supported by 
laboratory experiments which demonstrated that during short-term exposures (14-d), viz. a

236 period of time insufficient to allow for any possible adaptation mechanisms to occur, uptake 237 of $\mathrm{Ag}, \mathrm{Cd}, \mathrm{Co}, \mathrm{Cr}, \mathrm{Mn}, \mathrm{Ni}$ and $\mathrm{Zn}$ in L. variegata from a single population was linear over the 238 duration of the experiments and reached tissue concentrations that were directly proportional 239 to the metal concentrations in seawater (over 2 to 3 orders of magnitude) (Metian et al. 2006, 240 2008b).

241 The strong bioaccumulation capacity for $\mathrm{Ag}, \mathrm{As}, \mathrm{Cd}, \mathrm{Co}, \mathrm{Cr}, \mathrm{Cu}, \mathrm{Mn}$ and $\mathrm{Ni}$ and the 242 ability of the alga to provide quantitative information on contaminant levels in its 243 environment, as indicated by both previous laboratory studies and the present field work, 244 converge in demonstrating the usefulness of L. variegata as a bioindicator species in the New 245 Caledonia lagoon.

246 For biomonitoring purposes, contaminant levels can be monitored in the marine 247 environment through the use of resident algae, since they were shown to be able to 248 discriminate different locations according to their level of contamination (Hédouin 2006, 249 present study). However, our study also indicates that the use of transplanted algae would 250 allow obtaining information that is more discriminating (since concentrations of several 251 contaminants are higher in transplanted algae than in the resident ones) and that reflects more 252 quantitatively the contaminant concentrations in the ambient seawater. Indeed a proportional relationship between contaminant concentrations in transplanted algae and that in the 254 environment exists (as has been shown experimentally, Metian et al. 2006, 2008b) but a 255 breakdown in this relationship may occur for resident algae, probably due to certain 256 adaptation mechanisms as discussed above. Hence, the use of transplanted algae could be a 257 more sensitive and discriminating tool than resident algae to assess the level of metal 258 contamination in the New Caledonia coastal zone, as it would avoid interference by such 259 possible adaptation mechanisms. 
Whereas L. variegata showed a rapid and efficient response time when transplanted to a contaminated environment, the case was very different when algae were transplanted from the contaminated bay to the reference site. Indeed, except for Co where some significant depuration occurred, our study showed that the concentrations of the other elements were basically unchanged after 3 months of transplantation. These observations contrast somewhat with the results from previous laboratory experiments on $L$. variegata which suggested that some metals were characterized by relatively fast turnover rates in the alga, with short biological half-lives $\left(\mathrm{T}_{\mathrm{b}^{1 / 2}}\right)$ of about 1 month for $\mathrm{Cr}, \mathrm{Mn}$, and $\mathrm{Zn}$ and 1 week for Ni (Metian et al. 2006, 2008b).

The Phaeophyceae, to which L. variegata belongs, are well known to strongly bind metal ions (see e.g., Bryan 1984), both via cell wall adsorption (biosorption) and cell absorption with subsequent strong binding to intracellular macromolecules such as polyphenols, phytochelatins and metallothioneins (e.g. Ragan et al. 1979; Morris et al. 1999; Cobbett and Goldsbrough 2002). Polyphenols are present in very large proportions in L. variegata (viz., typically from 8 to $13 \%$ of the total algal dry wt; Targett et al. 1992). Therefore it is quite likely that cell absorption would be the predominant accumulation process in this species.

Besides being responsible for the high bioconcentration efficiency of L. variegata, the elevated content in these metal-binding macromolecules could also explain the virtual lack of depuration of certain elements in the algae transplanted from the contaminated site to the reference station during our experiment. Indeed, past exposure history may influence further 280 contaminant elimination, as has been reported for example in oysters (e.g., Wallner281 Kersanach et al. 2000). Therefore, if algae from the contaminated area have developed 282 efficient detoxification strategies based on metal sequestration (e.g. via their elevated content in polyphenols), most of the tissue-associated metal pool would be strongly bound to intracellular components, which would logically result in high initial metal retention when 
285 transplanted into a less contaminated area. Nevertheless, in order to better understand 286 depuration and detoxification processes of metals in L. variegata, further experimental studies 287 should be conducted using long-term depuration experimental designs and with algae having 288 different metal exposure histories. This could be done by carrying out field depuration 289 experiments with (1) algae coming from a contaminated sites and (2) algae collected from a 290 reference site, then transplanted for a few months into a contaminated site prior to being 291 replaced in the reference site to follow metal depuration, in parallel with regular measurements of the intracellular content of metal-binding macromolecules.

Regarding the particular case of $\mathrm{Mn}$ and $\mathrm{Zn}$, an increase in concentration was observed in 294 the algae collected from the contaminated site (Boulari Bay) and transplanted in the reference 295 site (Maa Bay). However, a similar and concomitant increase in Mn and $\mathrm{Zn}$ concentrations 296 was measured in the resident algae from Boulari Bay. This observation strongly suggests that 297 this change in metal concentrations was due to some specific physiological parameters in the 298 algae rather than to an uptake of $\mathrm{Mn}$ and $\mathrm{Zn}$ in relation to the level of contamination in the 299 site of transplantation. This assumption is further supported by the fact that the Maa Bay 300 algae that were transplanted to Boulari Bay actually took up Mn very efficiently (tissue 301 concentrations increased by two orders of magnitude), thus indicating that, in terms of 302 bioavailable metal levels, Maa Bay is actually similarly ( $\mathrm{Zn})$ or much less (Mn) contaminated 303 than Boulari Bay. 


\section{Conclusion}

The cross-transplantation experiments clearly demonstrated that the alga $L$. variegata is a

308 powerful and informative bioindicator of metal contamination in the New Caledonia lagoon.

309 It displays high bioconcentration capacities, especially for $\mathrm{Co}, \mathrm{Cr}, \mathrm{Mn}$ and $\mathrm{Ni}$, which are the main elements of concern in this region due to their worldwide importance in the context of

311 Ni-ore exploitation. The present in situ transplantation study has also provided essential data regarding the relevance and usefulness of using this species for active biomonitoring, and complements a former study on the use of resident $L$. variegata populations for surveying 314 metal contamination (passive biomonitoring) (Hédouin 2006). Hence this new information

315 allows extending monitoring studies to areas of the New Caledonia lagoon where L. variegata does not occur naturally.

Finally, due to the wide distribution of the brown alga L. variegata in tropical areas

318 (Targett et al. 1992), our study further underscores the usefulness of this algal species as a 319 tool for biomonitoring metal contamination levels in other tropical environments where 320 adequate bioindicators may be lacking.

\section{Acknowledgments}

324 The authors gratefully thank O. Pringault (IRD-Nouméa) for assistance in the field and C. 325 Churlaud (CCA, Univ. La Rochelle) for technical assistance at the ICP facilities. LH was 326 beneficiary of a PhD grant (CIFRE, France) supported by the Goro-Nickel Company, New

327 Caledonia. MW is an Honorary Senior Research Associate of the National Fund for Scientific 328 Research (NFSR, Belgium) and holds a 2008 Invited Expert position at LIENSs (Université 
de La Rochelle), supported by the Conseil Régional de Poitou-Charentes. This work was

330 supported by the IAEA, the IRD and the French PNEC Programme (Chantier Nouvelle331 Calédonie). The IAEA is grateful for the support provided to its Marine Environment 332 Laboratories by the Government of Monaco.

\section{References}

Amado Filho, G.M., Andrade, L.R., Karez, C.S., Farina, M., Pfeiffer, W.C. 1999. Brown algae species as biomonitors of $\mathrm{Zn}$ and $\mathrm{Cd}$ at Sepetiba Bay, Rio de Janeiro, Brazil. Marine Environmental Research 48, 213-224.

Ambatsian, P., Fernex, F., Bernat, M., Parron, C., Lecolle, J. 1997. High metal inputs to closed seas: the New Caledonia lagoon. Journal of Geochemical Exploration 59, 59-74.

Bird, E.C.F., Dubois, J.P., Iltis, J.A. 1984. The impacts of opencast mining on the rivers and coasts of New Caledonia. United Nations University Press, Tokyo.

Bryan, G.W. 1983. Brown seaweed, Fucus vesiculosus, and the gastropod, Littorina littoralis, as indicators of trace-metal availability in estuaries. Science of the Total Environment 28,

Bryan, G.W. 1984. Pollution due to heavy metals and their compounds. Marine Ecology 5, $1290-1331$.

Burrows, E.M. 1971. Assessment of pollution effects by the use of algae. Proceedings of the Royal Society of London B Biological Sciences 177, 295-306.

Cobbett, C., Goldsbrough, P. 2002. Phytochelatins and metallothioneins: roles in heavy metal detoxification and homeostasis. Annual Review of Plant Biology 53, 159-182.

Coteur G., Gosselin P., Wantier P., Chambost-Manciet Y., Danis B., Pernet P., Warnau M., Dubois P. 2003. Echinoderms as bioindicators, bioassays, and impact assessment tools of 
sediment-associated metals and PCBs in the North Sea. Archives of Environmental Contamination and Toxicology 45, 190-202.

Fichez, R., Adjeroud, M., Bozec, Y.M., Breau, L., Chancerelle, Y., Chevillon, C., Douillet, P., Fernandez, J.M., Frouin, P., Kulbicki, M., Moreton, B., Ouillon, S., Payri, C., Perez, T., Sasal, P., Thébault, J. 2005. A review of selected indicators of particle, nutrient and metal inputs in coral reef lagoon systems. Aquatic Living Resources 18, 125-147.

Försberg, A., Söderlung, S., Frand, A., Petersson, L.R., Pedresén, M. 1988. Studies on metal content in the brown seaweed, Fucus vesiculosus, from the Archipelago of Stockholm. Environmental Pollution 49, 245-263.

Hédouin, L., Metian, M., Cotret, O., Teyssié, J.L., Fowler, S.W., Fichez, R., Warnau, M. 2006. Allometric relationships in the bioconcentration of heavy metals by the edible tropical clam Gafrarium tumidum. Science of the Total Environment 366, 154-163.

Hédouin, L., Pringault, O., Metian, M., Bustamante, P., Warnau, M. 2007. Nickel bioaccumulation in bivalves from the New Caledonia lagoon: Seawater and food exposure. Chemosphere 66, 1449-1457.

Hédouin, L., Bustamante, P., Churlaud, C., Pringault, O., Fichez, R., Warnau, M. 2008. Trends in concentrations of selected metalloid and metals in two bivalves from the SW lagoon of New Caledonia. Ecotoxicology and Environmental Safety (in press, doi:10.1016/j.ecoenv.2008.04.004).

Hédouin, L. 2006. Caractérisation d'espèces bioindicatrices pour la surveillance des activités minières et la gestion de l'environnement en milieu récifal et lagonaire: application au lagon de Nouvelle-Calédonie. Ph.D. Thesis, Océanologie Biologique et Environnement Marin, University of La Rochelle, France.

Hoegh-Guldberg, O. 1999. Climate change, coral bleaching and the future of the world's coral reefs. Marine and Freshwater Research 50, 839-866. 
Karez, C.S., Magalhaes, V.F., Pfeiffer, W.C., Amado Filho, G.M. 1994. Trace metal accumulation by algae in Sepetiba Bay, Brazil. Environmental Pollution 83, 351-356.

381 Klerks, P.L., Weis, J.S. 1987. Genetic adaptation to heavy metals in aquatic organisms: a review. Environmental Pollution 45, 173-205.

Labrosse, P., Fichez, R., Farman, R., Adams, T. 2000. New Caledonia, in: Sheppard, C.R.C. (Ed.), Seas at the Millenium: an environmental evaluation. Pergamon, Amsterdam, pp. 723-736.

Laganier, R. 1991. Erosion, transport and sedimentation processes associated with opencast mining in New Caledonia: interactions with weather and climate, in: ORSTOM (Ed.), South Pacific environments: interactions with weather and climate. New Zealand, pp. 8385.

Ma, X.L., Cowles, D.L., Carter, R.L. 2000. Effect of pollution on genetic diversity in the bay mussel Mytilus galloprovincialis and the acorn barnacle Balanus glandula. Marine Environmental Research 50, 559-563.

Metian, M., Hédouin, L., Barbot, C., Teyssié, J.L., Fowler, S.W., Goudard, F., Bustamante, P., Durand, J.P., Piéri, J., Warnau, M, 2005. Use of radiotracer techniques to study subcellular distribution of metals and radionuclides in bivalves from the Noumea Lagoon,

Metian, M., Hédouin, L., Giron, E., Buschiazzo, E., Borne, V., Paganelli, J., Boudjenoun, R., Cotret, O., Teyssié, J.L., Fowler, S.W., Warnau, M. 2006. Bioaccumulation of selected heavy metals in the brown alga Lobophora variegata: a radiotracer study, in: Isotopes in Environmental Studies, IAEA-CSP-26. IAEA, Vienna, pp. 323-324.

Metian, M., Bustamante, P., Hédouin, L., Warnau, M. 2008a. Accumulation of trace elements 402 in the tropical scallop Comptopallium radula from coral reefs in New Caledonia. Environmental Pollution 152, 543-552. 
Metian, M., Giron, E., Borne, V., Hédouin, L., Teyssié, J.L., Warnau, M. 2008b. The brown alga Lobophora variegata, a bioindicator species for surveying metal contamination in tropical marine environments. Journal of Experimental Marine Biology and Ecology 362, 49-54.

Morris, C.A., Nicolaus, B., Sampson, V., Harwood, J.L., Kille, P. 1999. Identification and characterization of a recombinant metallothionein protein from a marine alga, Fucus vesiculosus. The Biochemical Journal 338, 553-560.

O'Connor, T.P. 1998. Mussel Watch results from 1986 to 1996. Marine Pollution Bulletin 37, 14-19.

Phillips, D.J.H. 1990. Use of macroalgae and invertebrates as monitors of metal levels in estuaries and coastal waters, in: Furness, R.W., Rainbow, P.S. (Eds.), Heavy metals in the marine environment. CRC Press, Boca Raton, pp. 81-99.

Ragan, M.A., Smidsrod, O., Larsen, B. 1979. Chelation of divalent metal ions by brown algal polyphenols. Marine Chemistry 7, 265-271.

Rainbow, P.S. 2002. Trace metal accumulation in aquatic invertebrates: why and so what? Environmental Pollution 120, 497-507.

Söderlund, S., Forsberg, A., Pedersen, M. 1988. Concentrations of cadmium and other metals in Fucus vesiculosus L. and Fontinalis dalecarlica Br. Eur. from the northern Baltic Sea and the southern Bothnian Sea. Environmental Pollution 51, 197-212.

Targett, N.M., Coen, L.C., Boettcher, A.A., Tanner, C.E. 1992. Biogeographic comparisons of marine algal polyphenolics: evidence against a latitudinal trend. Oecologia 89, 464470.

Temara A., Aboutboul P., Warnau M., Jangoux M., Dubois P. 1998. Uptake and fate of lead in the common asteroid Asterias rubens (Echinoderm). Water, Air, and Soil Pollution 102, 201-208. 
429 Wallner-Kersanach, M., Theede, H., Eversberg, U., Lobo, S. 2000. Accumulation and 430 elimination of trace metals in a transplantation experiment with Crassostrea rhizophorae. 431 Archives of Environmental Contamination and Toxicology 38, 40-45.

432 Warnau, M., Bustamante, P. 2007. Radiotracer techniques: a unique tool in marine 433 ecotoxicological studies. Environmental Bioindicators 2, 217-218.

434 Warnau, M., Teyssié, J.L., Fowler, S.W. 1995. Effect of feeding on cadmium 435 bioaccumulation in the echinoid Paracentrotus lividus (Echinodermata). Marine Ecology 436 Progress Series 126, 305-309.

437 Warnau, M., Teyssié, J.L., Fowler, S.W. 1996. Biokinetics of selected heavy metals and 438 radionuclides in two marine macrophytes: the seagrass Posidonia oceanica and the alga 439 Caulerpa taxifolia. Marine Environmental Research 41, 343-362.

440 Warnau, M., Teyssié, J.L., Fowler, S.W. 1997. Cadmium bioconcentration in the echinoid 441 Paracentrotus lividus: influence of the cadmium concentration in sea water. Marine 442 Environmental Research 43, 303-314.

443 Zar, J.H. 1996. Biostatistical analysis. Prentice-Hall, Upper Saddle River, New Jersey. 
446 Captions to Figures

449 Figure 1. Map indicating the location of the transplantation sites: Maa Bay and Boulari Bay, $450 \quad$ New Caledonia.

453 Figure 2. Element concentrations $\left(\mu \mathrm{g} \mathrm{g}^{-1}\right.$ dry wt; mean $\left.\pm \mathrm{SD} ; \mathrm{n}=5\right)$ in Lobophora variegata 454 transplanted from Maa Bay (reference site) to Boulari Bay (contaminated site).

455 Solid lines indicate significant variation in element concentrations in transplanted algae (T456 BOU); dash lines indicate element concentrations in the resident algal population of Maa Bay 457 (Control MAA; $\mathrm{n}=30$ ).

460 Figure 3. Element concentrations $\left(\mu \mathrm{g} \mathrm{g}^{-1}\right.$ dry wt; mean $\left.\pm \mathrm{SD} ; \mathrm{n}=5\right)$ in Lobophora variegata 461 transplanted from Boulari Bay (contaminated site) to Maa Bay (reference site).

462 Solid lines indicate significant variation in element concentrations in transplanted algae (T463 MAA); dash lines indicate element concentrations in the resident algal population of Boulari 464 Bay (Control BOU; $\mathrm{n}=30$ ). 


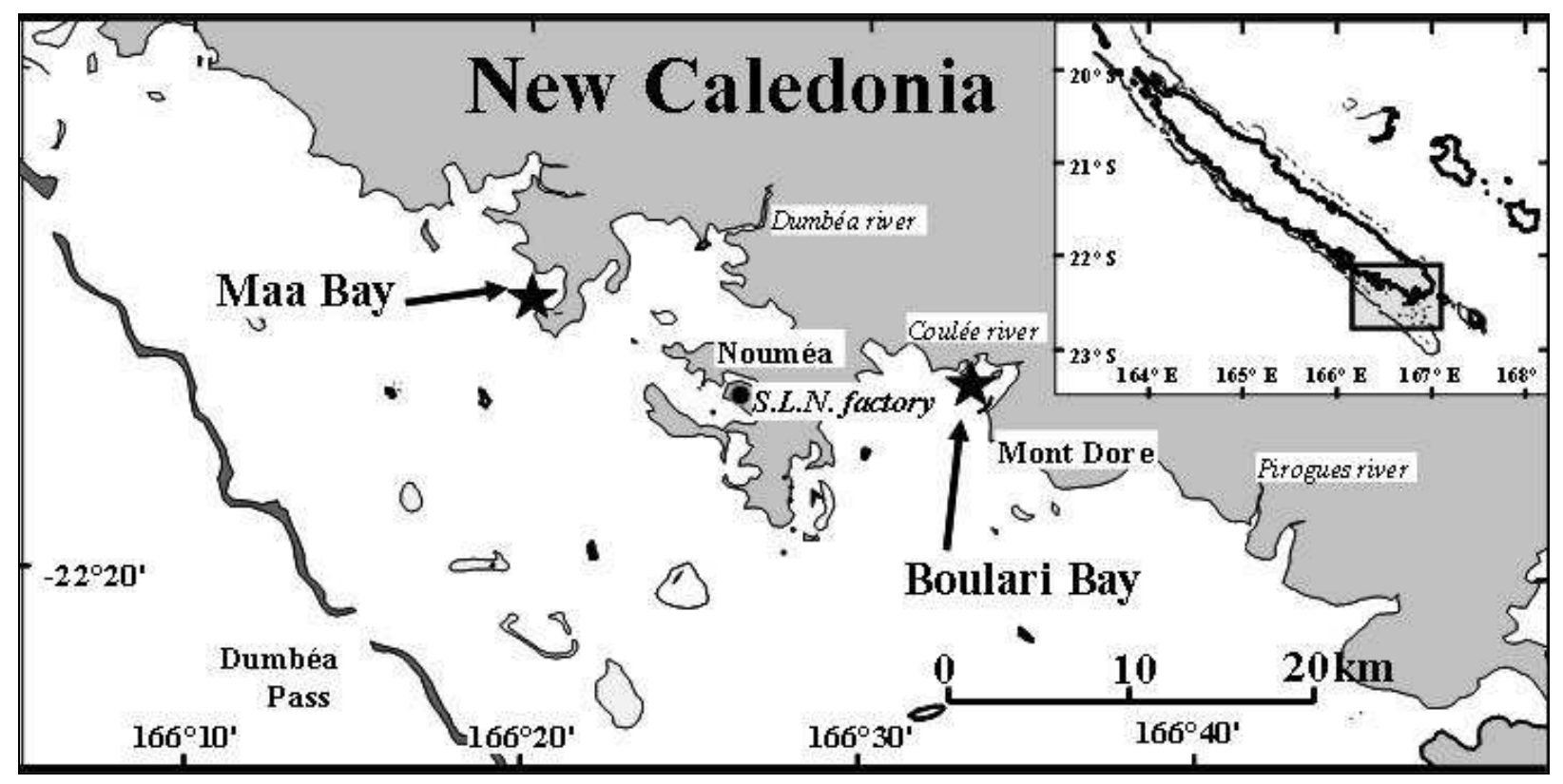

Figure 1 

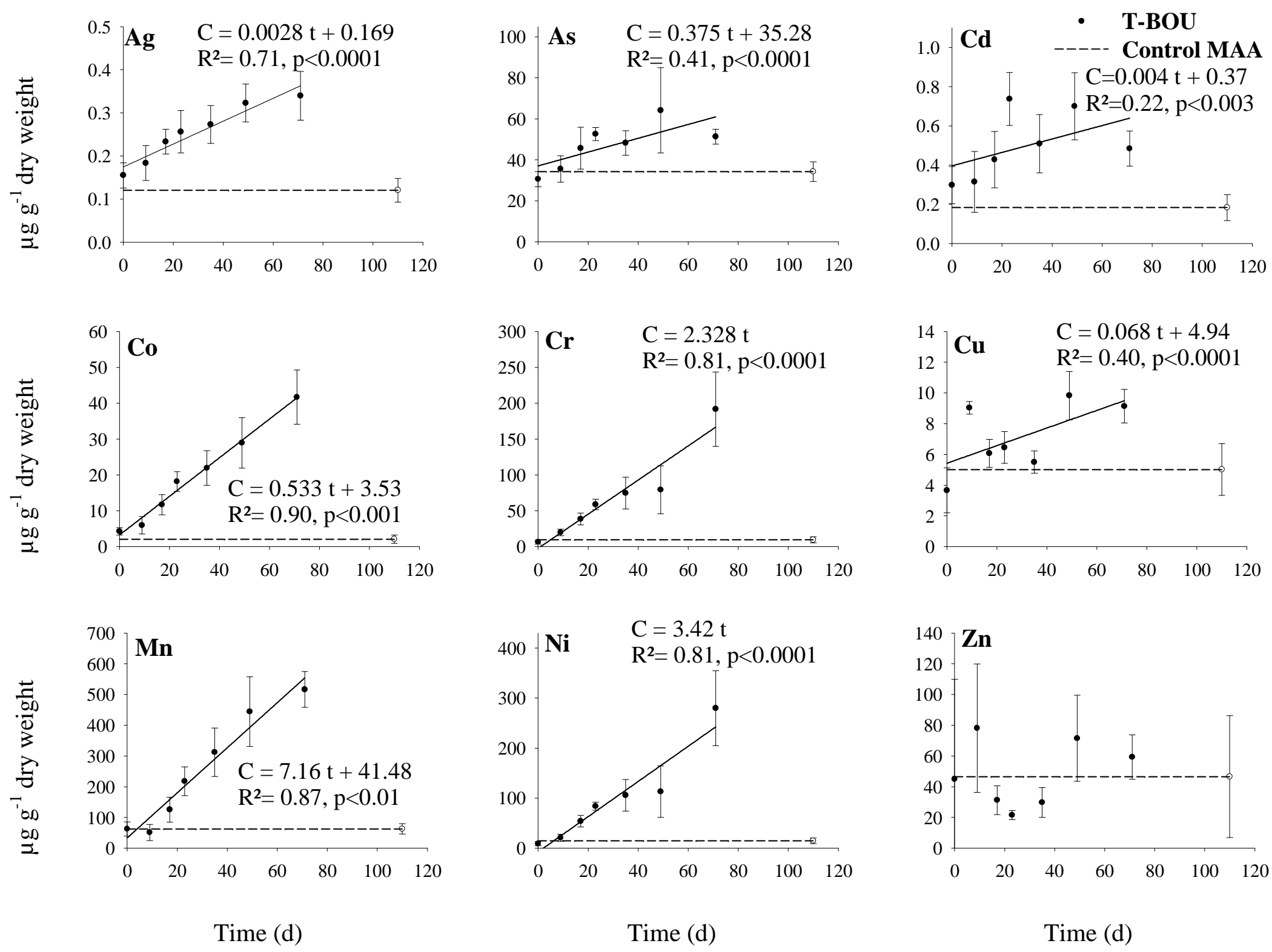
Figure 2
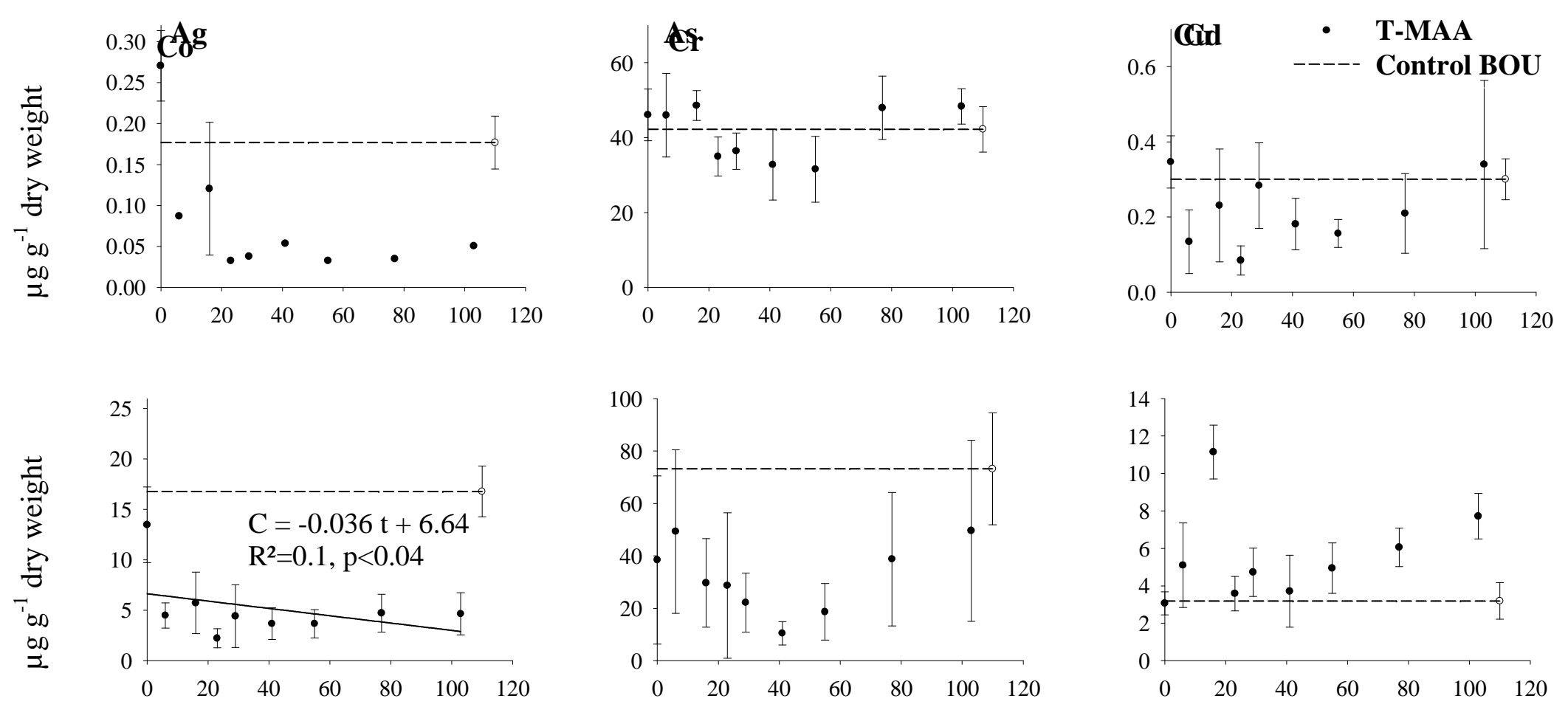


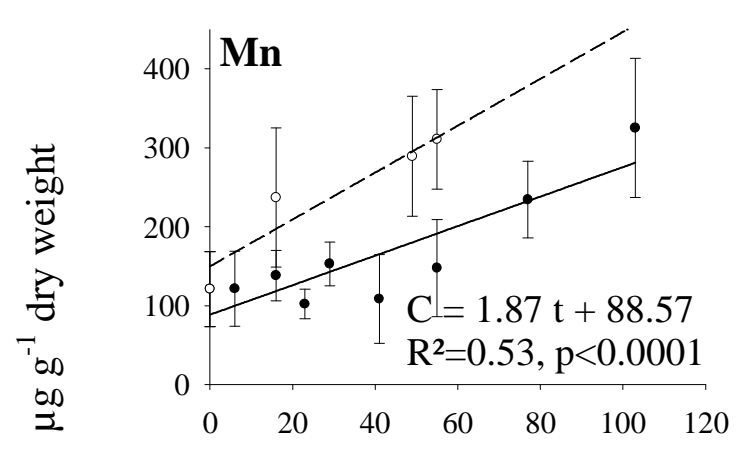

Time (d)

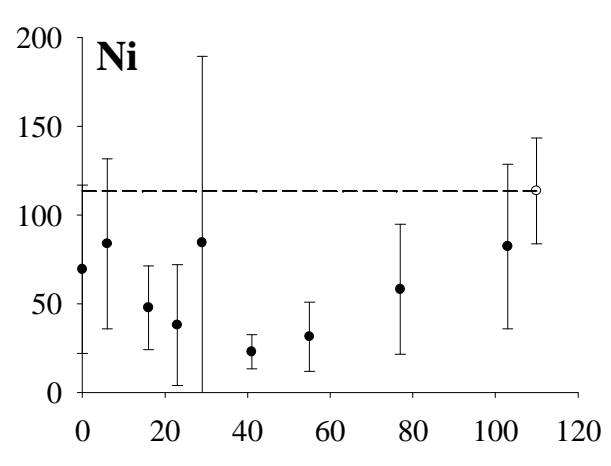

Time (d)

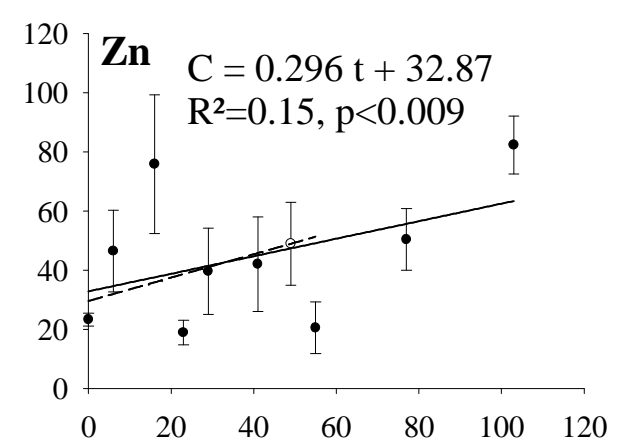

Time (d)

Figure 3 
Table 1. ICP-OES and ICP-MS analyses of two certified reference materials: certified and measured values (mean $\pm \mathrm{SD} ; \mu \mathrm{g} \mathrm{g}^{-1}$ dry $\mathrm{wt} ; \mathrm{n}=5$ ) and recovery $(\%)$.

\begin{tabular}{|c|c|c|c|c|c|c|c|}
\hline \multirow{2}{*}{ Elements } & \multirow{2}{*}{ Method } & \multicolumn{3}{|c|}{ TORT-2 } & \multicolumn{3}{|c|}{ DOLT-3 } \\
\hline & & Measured & Certified & \% Recovery & Measured & Certified & \% Recovery \\
\hline$\overline{A g}$ & ICP-MS & & & & $1.07 \pm$ & $1.20 \pm 0.07$ & 89 \\
\hline As & ICP-OES & $22.3 \pm 2.2$ & $21.6 \pm 1.8$ & 103 & $9.45 \pm 0.97$ & $10.20 \pm 0.50$ & 93 \\
\hline Cd & ICP-MS & $26.4 \pm 3.8$ & $26.7 \pm 0.6$ & 99 & $17.0 \pm 3.1$ & $19.4 \pm 0.6$ & 88 \\
\hline Co & ICP-MS & $0.52 \pm 0.09$ & $0.51 \pm 0.09$ & 102 & & & \\
\hline $\mathrm{Cr}$ & ICP-OES & $0.66 \pm 0.19$ & $0.77 \pm 0.15$ & 85 & & & \\
\hline $\mathbf{C u}$ & ICP-OES & $98.4 \pm 11.2$ & $106.0 \pm 10.0$ & 93 & $31.2 \pm 2.4$ & $31.2 \pm 1.0$ & 100 \\
\hline Mn & ICP-OES & $12.5 \pm 1.2$ & $13.6 \pm 1.2$ & 92 & & & \\
\hline $\mathbf{N i}$ & ICP-OES & $2.02 \pm 0.35$ & $2.50 \pm 0.19$ & 81 & $3.05 \pm 0.76$ & $2.72 \pm 0.35$ & 112 \\
\hline $\mathbf{Z n}$ & ICP-OES & $188 \pm 20$ & $180 \pm 6$ & 104 & $97.7 \pm 7.0$ & $86.6 \pm 2.4$ & 113 \\
\hline
\end{tabular}

